\title{
CD15 Negative
}

National Cancer Institute

\section{Source}

National Cancer Institute. CD15 Negative. NCI Thesaurus. Code C162064.

An indication that CD15 antigen expression has not been detected in a sample. 